\title{
PERAN KPU DALAM MENGATASI BLACK CAMPAIGN (Studi Pada Kantor KPU Kabupaten Tulungagung)
}

\author{
Laily Purnawati \\ lailypurnawatisip@gmail.com \\ Erik Nasrul Fajar \\ eriknasrul5@gmail.com
}

\section{ABSTRAK}

Penelitian ini dilatar belakangi oleh adanya aksi black campaign dalam pelaksanaan pemilu yang dapat merugikan salah satu pihak tertentu, serta memicu polemik dalam masyarakat. Peran KPU sebagai lembaga pemerintah sangat penting dalam rangka mensukseskan pemilu , terutama terhadap adanya tindak black campaign guna mereduksi adanya tindak pelanggaran tersebut .

Adapun perumusan masalah skripsi ini adalah (1) Bagaimana peran Komisi Pemilihan Umum (KPU) Kabupaten Tulungagung dalam mengatasi black campaign pada pelaksanaan Pemilu 2019 di Kabupaten Tulungagung ? (2) Faktor apa saja yang menjadi pendorong dan penghambat peran Komisi Pemilihan Umum (KPU) Kabupaten Tulungagung pada pelaksanaan Kampanye Pemilu 2019 di Kabupaten Tulungagung?.

Skripsi ini disusun berdasarkan data lapangan menggunakan pendekatan kualitatif dengan jenis penelitian deskriptif . Objek penelitian ini adalah di Kantor KPU Kabupaten Tulungagung. Teknik pengumpulan data dilakukan melalui observasi, wawancara, dokumentasi .

Hasil Penelitian: Komisi Pemilihan Umum (KPU) tidak punya wewenang penuh dalam penindakan terhadap pelaku pelanggaran seperti kampanye hitam (black campaign). Penindakan tersebut menjadi tugas dan wewenang dari Badan Pengawas Pemilu (BAWASLU). Adapun faktor pendorong dan penghambat peran Komisi Pemilihan Umum (KPU) Kabupaten Tulungagung pada pelaksanaan Kampanye Pemilu 2019 di Kabupaten Tulungagung antara lain: a) Faktor pendorong meliputi: antusiasme masyarakat, pemahaman masyarakat yang relatif bagus terhadap Pemilu, support dari instansi terkait; b) Faktor penghambat meliputi: penggunaan media sosial yang tidak semestinya , sikap pragmatisme masyarakat .

Kata Kunci : Peran Komisi Pemilihan Umum (KPU), Black Campaign 


\section{ABSTRACT}

This research is motivated by the existence of black campaign actions in the implementation of elections that can be detrimental to certain parties, as well as triggering polemics in the community. The role of the KPU as a government agency is very important in order to succeed the election, especially against the existence of black campaign actions to reduce the existence of such violations .

The formulation of this thesis problem is (1) What is the role of the General Election Commission (KPU) of Tulungagung Regency in overcoming the black campaign in the implementation of the 2019 Elections in Tulungagung Regency ? (2) What factors are driving and inhibiting the role of the General Election Commission (KPU) of Tulungagung Regency in the implementation of the 2019 Election Campaign in Tulungagung Regency?

This research is based on field data using a qualitative approach to the type of descriptive research. The object of this research is the Office of the General Election Commission of Tulungagung Regency. Data collection techniques are done through observation, interviews, documentation .

Research Results: The General Election Commission (KPU) does not have full authority in prosecuting violators such as the black campaign. Enforcement is the duty and authority of the Election Oversight Body (BAWASLU). The factors driving and inhibiting the role of the General Election Commission (KPU) of Tulungagung Regency in the implementation of the 2019 Election Campaign in Tulungagung Regency include: a) The driving factors include : community enthusiasm, a relatively good understanding of the general public in the General Election, support from the relevant agencies; b) Inhibiting factors include: the improper use of social media, the attitude of community pragmatism .

\section{Keywords: Role of the General Election Commission (KPU), Black Campaign}

\section{PENDAHULUAN}

\section{A. Latar Belakang}

Negara Republik Indonesia merupakan negara yang menganut paham demokrasi sebagaimana yang ditegaskan dalam Undang- Undang Dasar Republik Indonesia Tahun 1945. Pemilihan umum (pemilu) merupakan sebuah sarana di negara demokrasi dimana rakyat berhak dan bebas untuk menyalurkan suara guna menentukan pilihan perwakilannya di kursi pemerintahan. Pemilu secara langsung oleh rakyat merupakan perwujudan kedaulatan rakyat guna menghasilkan pemerintahan negara




kampanye hitam (black campaign) yang dapat merugikan berbagai pihak karena berpotensi memicu permasalahan lain dikemudian hari .

Hal ini sesuai dengan salah satu tugas KPU yang disebutkan dalam Undang- Undang No. 7 Tahun 2017 Pasal 12 huruf (i) yang berbunyi, " KPU bertugas menindaklanjuti dengan segera putusan Bawaslu atas temuan dan laporan adanya dugaan pelanggaran atau sengketa pemilu". Menurut Tito Karnavian dalam Puspita(2019) black campaign adalah kampanye yang mengabarkan sesuatu tentang lawan yang tidak berdasarkan fakta. ( Ratna,2019).

( https://www.republika.co.id)

$$
\text { Kabupaten }
$$

Tulungagung merupakan salah satu tempat penyenggaraan pemilu yang pernah mengalami adanya kasus black campaign,( MenurutAnang Basso, 2019) dimana dalam kurun waktu masa kampanye pemilihan legislatif (pileg) Kabupaten Tulungagung telah terjadi perusakan terhadap alat peraga kampanye milik salah satu calon legislatif (caleg) nomor urut 1 daerah pemilihan (dapil) 1 yang diusung oleh Partai Solidaritas Indonesia (PSI), yaitu Cornella . Perusakan alat peraga kampanye caleg tersebut berupa adanya aksi vandalisme dengan melakukan pencoretan foto caleg serta menambahkan tulisan "PKI" pada alat peraga kampanye caleg tersebut. Kejadian ini terjadi pada alat peraga kampanye Cornella yang dipasang di sepanjang jalan raya Desa Tapan, Kecamatan Kedungwaru, Tulungagung . Adanya tindakan tersebut, berarti telah melanggar UU No.8 Tahun 2012 Pasal 86 ayat (1) huruf (g) yang berbunyi "Pelaksana, peserta, dan petugas kampanye pemilu dilarang merusak dan/atau menghilangkan alat peraga kampanye peserta pemilu" . (htttps://www.tulungagungtimes.com)

Adanya aksi black campaign dalam pelaksanaan pemilu dapat merugikan salah satu pihak tertentu, bahkan dapat memicu polemik dalam masyarakat sehingga akan mengganggu kekondusifan sosial. Hal tersebut sangat membahayakan stabilitas nasional apabila terus terjadi dalam setiap pelaksanaan pemilu. Maka dari itu, peran KPU dalam melakukan pengawasan dan penyelenggaraan pemilu sangat penting dalam rangka mensukseskan pemilu-pemilu selanjutnya, baik pilkada, pileg, maupun pilpres serta mencegah adanya tindak black campaign yang dapat menganggu stabilitas nasional. Penelitian ini bertujuan untuk mengetahui peranan 
KPU sebagai lembaga pemerintah terhadap adanya tindak black campaign guna melakukan evaluasi pelaksanaan pemilu sebelumnya dan memberikan saran yang membangun kepada KPU sehingga dapat menjaga stabilitas sosial baik sebelum, selama, maupun pasca dilaksanakan pemilu . Penelitian ini dilakukan dengan mengambil studi kasus perusakan alat peraga kampanye yang pernah terjadi di wilayah Desa Tapan, Kecamatan Kedungwaru,

Kabupaten

Tulungagung .

\section{B. Rumusan Masalah}

Berdasarkan uraian latar belakang dan permasalahan tersebut di atas, maka penulis mencoba mengidentifikasikan beberapa permasalahan sebagai berikut :

1. Bagaimana peran Komisi Pemilihan $\begin{array}{llr}\text { Umum (KPU) } & \text { Kabupaten } \\ \text { Tulungagung dalam } & \text { mengatasi } \\ \text { black campaign pada } & \text { pelaksanaan } \\ \text { Pemilu } 2019 \text { di } & \text { Kabupaten } \\ \text { Tulungagung? } & \end{array}$

2. Faktor apa saja yang menjadi pendorong dan penghambat peran Komisi Pemilihan Umum (KPU) Kabupaten Tulungagung pada pelaksanaan Kampanye Pemilu 2019 di Kabupaten Tulungagung ?

\section{Tujuan Penelitian}

Tujuan penelitian yang hendak dicapai dari penulisan skripsi ini adalah sebagai berikut :

1. Untuk mendeskripsikan dan menganalisa peran Komisi Pemilihan Umum (KPU) Kabupaten Tulungagung dalam mengatasi "black campaign" yang terjadi di Kabupaten Tulungagung .

2. Untuk mendeskripsikan dan menganalisa faktor pendorong dan penghambat peran Komisi Pemilihan Umum (KPU) Kabupaten Tulungagung pada pelaksanaan Kampanye Pemilu 2019 di Kabupaten Tulungagung .

\section{TINJAUAN PUSTAKA}

\section{A. Pengertian Pemilu}

Pengisian lembaga perwakilan dalam praktek ketatanegaraan lazimnya dilaksanakan melalui Pemilihan Umum. Pasca perubahan amandemen UUD 1945 , semua anggota lembaga perwakilan dan bahkan presiden serta Kepala Daerah dipilih dengan mekanisme Pemilihan Umum. Pemilihan umum menjadi agenda yang diselenggarakan secara berkala di Indonesia .

Ibnu Tricahyo dalam bukunya yang berjudul Reformasi Pemilu, mendefinisikan Pemilihan Umum sebagai berikut: 
"Secara universal Pemilihan

Umum adalah instrumen mewujudkan kedaulatan rakyat yang bermaksud membentuk pemerintahan yang absah serta sarana mengartikulasikan aspirasi dan kepentingan rakyat" (Tricahyo, 2009:6) .

Definisi di atas menjelaskan bahwa pemilihan umum merupakan instrumen untuk mewujudkan kedaulatan rakyat, membentuk pemerintahan yang absah serta sebagai sarana mengartikulasi aspirasi dan kepentingan rakyat. Negara Indonesia mengikutsertakan rakyatnya dalam rangka penyelenggaraan negara . Kedaulatan rakyat dijalankan oleh wakil rakyat yang duduk dalam parlemen dengan sistem perwakilan (representative democracy) atau demokrasi tidak langsung (indirect democracy). Wakil-wakil rakyat ditentukan sendiri oleh rakyat melalui Pemilu (general election) .

Soedarsono mengemukakan lebih lanjut dalam bukunya yang berjudul Mahkamah Konstitusi Pengawal Demokrasi, bahwa yang dimaksud dengan pemilihan umum adalah sebagai berikut:

"Pemilihan umum adalah syarat minimal bagi adanya demokrasi dan diselenggarakan dengan tujuan memilih wakil rakyat, wakil daerah, presiden untuk membentuk pemerintahan demokratis" (Soedarsono, 2005:1) .

Penjelasan di atas menyebutkan bahwa pemilihan umum merupakan syarat minimal adanya demokrasi yang bertujuan memilih wakil-wakil rakyat, wakil daerah, presiden untuk membentuk pemerintahan demokratis . Kedaulatan rakyat dijalankan oleh wakil-wakil rakyat yang duduk di dalam lembaga perwakilan . Kedaulatan rakyat atas penyelenggaraan pemerintahan dijalankan oleh presiden dan Kepala Daerah yang juga dipilih secara langsung. Anggota legislatif maupun Presiden dan Kepala Daerah karena telah dipilih secara langsung, maka semuanya merupakan wakil-wakil rakyat yang menjalankan fungsi kekuasaan masing-masing.

Kedudukan dan fungsi wakil rakyat dalam siklus ketatanegaraan yang begitu penting dan agar wakilwakil rakyat benar- benar bertindak atas nama rakyat, maka wakil rakyat tersebut harus ditentukan sendiri oleh rakyat, yaitu melalui pemilihan umum .

Menurut Jimly Asshidiqqie pentingnya penyelenggaraan Pemilihan Umum secara berkala tersebut dikarenakan beberapa sebab diantaranya sebagai berikut : 
1) pendapat atau aspirasi rakyat cenderung berubah dari waktu ke waktu;

2) kondisi kehidupan masyarakat yang dapat juga berubah ;

3) pertambahan penduduk dan rakyat dewasa yang dapat menggunakan hak pilihnya ;

4) guna menjamin regulasi kepemimpinan baik dalam cabang eksekutif dan legislatif . (Asshidiqqie, 2006:169171).

Berdasarkan pernyataan di atas bahwa beberapa sebab pentingnya pemilihan umum diantaranya adalah aspirasi rakyat cenderung berubah, kondisi kehidupan rakyat berubah, pertambahan penduduk dan regulasi kepemimpinan. Pemilihan umum menjadi sarana untuk menyalurkan aspirasi rakyat. Kondisi kehidupan rakyat yang cenderung berubah memerlukan adanya mekanisme yang mewadahi dan mengaturnya yaitu melalui proses pemilihan umum. Setiap penduduk dan rakyat Indonesia yang telah dewasa memiliki hak untuk menggunakan hak pilihnya dalam pemilihan umum . Regulasi kepemimpinan baik cabang eksekutif maupun legislatif akan terlaksana secara berkala dengan adanya pemilihan umum .
B. Komisi Pemilihan Umum (KPU)

1. Pengertian Komisi Pemilihan Umum (KPU)

Menurut Jimly Asshiddiqie dalam bukunya yang berjudul Konstitusi dan Konstitusionalisme Indonesia mendefinsikan Komisi Pemilihan Umum Sebagai Berikut :

"Komisi Pemilihan Umum adalah lembaga negara yang menyelenggarakan pemilihan umum di Indonesia, yakni meliputi Pemilihan Umum ${ }^{1}$ Anggota DPR/'DPD/DPRD, Pemilihan Umum Presiden dan Wakil Presiden,serta Pemilihan Umum Kepala Daerah dan Wakil Kepala Daerah.Komisi Pemilihan Umum tidak dapat disejajarkan kedudukannya dengan lembaga- lembaga negara yang lain yang kewenangannya ditentukan dan diberikan oleh UUD 1945 . Bahkan nama Komisi Pemilihan Umum belum disebut secara pasti atau tidak ditentukan dalam UUD 1945, tetapi kewenangannya sebagai penyelenggara pemilihan umum sudah ditegaskan dalam Pasal 22E ayat (5) UUD 1945 yaitu Pemilihan umum diselenggarakan oleh suatu komisi pemilihan umum yang bersifat nasional, tetap, dan mandiri. Artinya, bahwa Komisi Pemilihan Umum itu adalah 
penyelenggara pemilu, dan sebagai penyelenggara bersifat

nasional , tetap dan mandiri (independen)" (Asshiddiqie, 2006:236-239).

Berdasarkan definisi di atas, yang dimaksud dengan komisi pemilihan umum adalah lembaga negara yang menyelenggarakan pemilihan umum di Indonesia yang bersifat nasional, tetap dan mandiri (independen). Pemilihan umum yang diselenggarakan oleh komisi pemilihan umum meliputi pemilihan Umum Anggota DPR/DPD/DPRD , Pemilihan

Umum Presiden dan Wakil Presiden, serta Pemilihan Umum Kepala Daerah dan Wakil Kepala Daerah . Kedudukan komisi pemilihan umum tidak ditentukan dalam UUD 1945 , maka kedudukan komisi pemilihan umum tidak dapat disejajarkan dengan lembaga- lembaga negara yang telah ditentukan dalam UUD 1945. Kewenangan komisi pemilihan umum sebagai penyelenggara pemilihan umum, hanya ditegaskan dalam Pasal 22E ayat (5) UUD 1945 yaitu Pemilihan umum diselenggarakan oleh suatu komisi pemilihan umum yang bersifat nasional, tetap, dan mandiri . Komisi pemilihan umum dengan demikian adalah penyelenggara pemilihan Umum, dan sebagai penyelenggara yang bersifat nasional, tetap dan mandiri (independen) .

Menururt Saldi Isra (2010) bahwa eksistensi Komisi pemilihan umum sebagai berikut:

"Secara normatif, eksistensi KPU untuk menyelenggarakan pemilu diatur di dalam Pasal 22E ayat (5) UUD 1945 yang menyebutkan bahwa penyelenggara pemilu oleh suatu komisi pemilihan umum . Kata suatu pada UUD 1945 menunjukkan makna subjek yang kabur dan tidak jelas, lain halnya dengan makna kata sebuah yang disebutkan pada kekuasaan kehakiman oleh sebuah MA dan MK" (Saldi Isra mahkamahkonstitusi.go.id).

Berdasarkan penjelasan di atas kedudukan komisi pemilihan umum tidak dapat disejajarkan dengan lembaga-lembaga negara lain yang kewenangannya ditentukan dan diberikan oleh UUD 1945. Hal tersebut disebabkan karena dalam Pasal 22E UUD 1945, nama Komisi Pemilihan Umum tidak disebutkan secara eksplisit dan tidak ditulis dengan huruf kapital. Nama Komisi Pemilihan Umum baru disebutkan 
secara pasti dalam UndangUndang Nomor 22 Tahun 2007 tentang Penyelenggara Pemilihan Umum .

\begin{tabular}{ccc}
\multicolumn{2}{c}{ Penjelasan mengenai } \\
eksistensi komisi
\end{tabular}
umum, lebih lanjut dijelaskan oleh Lukman Hakim sebagai berikut:

"Komisi pemilihan umum merupakan suatu komisi negara . Posisi komisi negara secara hierarki sebagai lembaga penunjang atas lembaga negara utama seperti MPR, DPR, DPD, Presiden, MA, MK dan BPK" ( Lukman Hakim, 2010:55) . Penjelasan di atas menyebutkan bahwa komisi pemilihan umum merupakan suatu komisi negara. Posisi komisi pemilihan umum secara hierarki adalah sebagai lembaga penunjang atas lembaga utama. Kedudukan Komisi pemilihan umum dengan demikian tidak dapat disejajarkan dengan lembaga- lembaga negara yang telah ditentukan dalam UUD 1945 .

Natabaya mengemukakan bahwa penafsiran mengenai posisi komisi pemilihan umum sebagai lembaga penunjang, dijelaskan sebagai berikut:

" penafsiran organ UUD 1945 terkelompok ke dalam dua bagian , yaitu main state organ (lembaga negara utama), dan auxiliary state organ (lembaga penunjang atau lembaga bantu). Komisi Pemilihan Umum merupakan organ konstitusi yang masuk dalam auxiliary state organ" (Natabaya, 2008:213) .

Berdasarkan teori organ negara di atas, Komisi Pemilihan Umum merupakan auxiliary state body, yaitu penunjang atas lembaga negara utama (main state organ). Komisi Pemilihan Umum secara hierarki termasuk dalam kategori auxiliary state organ yang kedudukannya sejajar dengan Menteri Negara, Tentara Nasional Indonesia, Kepolisian Negara, Komisi Yudisial, Komisi Ombudsman Indonesia dan Bank Sentral . Komisi pemilihan umum menunjang lembaga-lembaga negara utama sebagai penyelenggara pemilihan umum di negara Indonesia .

Ferry Kurnia Rizkiyansyah dalam bukunya yang berjudul Mengawal Pemilu Menatap Demokrasi, menyebutkan bahwa yang dimaksud dengan penyelenggara pemilihan umum adalah suatu lembaga khusus yang menangani proses pemilihan umum (Rizkiyansyah, 2007:78) . 
Definisi di atas menyebutkan bahwa penyelenggara pemilihan umum adalah lembaga khusus yang menangani proses pemilihan umum . Komisi pemilihan umum merupakan lembaga khusus yang menangani proses pemilihan umum di Indonesia . Komisi pemilihan umum sesuai dengan amanat UUD 1945 merupakan lembaga khusus penyelenggara pemilihan umum yang bersifat nasional, tetap dan mandiri .

Ketentuan mengenai penyelenggara pemilihan umum yang bersifat nasional, tetap dan mandiri telah ditindaklanjuti dalam Undang- undang Republik Indonesia Nomor 22 Tahun 2007 tentang Penyelenggara Pemilihan Umum . Komisi Pemilihan Umum sebagai lembaga independen ditunjukkan dalam Penjelasan Pasal 3 Undang-undang Republik Indonesia Nomor 22 Tahun 2007, yang menyebutkan bahwa Komisi Pemilihan Umum bersifat nasional, tetap dan mandiri . Yang dimaksud bersifat nasional yaitu mencerminkan bahwa wilayah kerja Komisi Pemilihan Umum sebagai penyelenggara pemilihan umum mencakup seluruh negara Republik Indonesia. Sifat tetap menunjukkan Komisi Pemilihan
Umum sebagai lembaga yang menjalankan tugas secara berkesinambungan meskipun dibatasi oleh masa jabatan tertentu. Sifat mandiri menegaskan Komisi Pemilihan Umum dalam menyelenggarakan dan melaksanakan pemilihan umum adalah bebas dari pengaruh pihak manapun. Penyelenggaraan pemilihan umum harus memberikan derajad kompetisi yang sehat, partisipatif dan mempunyai derajad keterwakilan yang tinggi sebagai amanat dari reformasi .

\section{Kampanye}

1. Pengertian Kampanye

Pada pemilihan umum tidak terlepas dari kegiatan kampanye. Kampanye dan pemilu bagai dua sisi mata uang yang tidak bisa dipisahkan satu sama lain. Kampanye adalah sebuah tindakan doktrin bertujuan mendapatkan pencapaian dukungan. Usaha kampanye bisa dilakukan perorangan atau sekelompok orang yang terorganisir untuk melakukan pencapaian suatu proses pengambil keputusan didalam suatu kelompok, kampanye juga bisa dilakukan guna untuk 
mempengaruhi, penghambatan, pembelokan pencapaian .

Menurut pasal 1 ayat 26 Undang- Undang Nomor 10 tahun 2008 tentang pemilihan umum DPR, DPD, DPRD yang disebut kampanye adalah kegiatan peserta pemilu untuk meyakinkan para pemilih dengan menawarkan visi, misi dan program peserta pemilu . Jadi berdasarkan pada definisi diatas arti kampanye adalah sebuah purpose to something . Kampanye adalah aktivitas komunikasi yang ditujukan untuk memengaruhi orang lain agar ia memiliki wawasan, sikap dan perilaku sesuai dengan kehendak atau keinginan penyebar atau pemberi informasi .

Sedangkan menurut Imawan ( dalam Cangara, 2011:223) mengungkapkan kampanye adalah upaya persuasive untuk mengajak orang lain yang belum sepaham atau belum yakin pada ide-ide yang kita tawarkan, agar mereka bersedia bergabung dan mendukungnya . Sementara pengertian kampanye yang dikemukakan oleh Kotler dan Roberto (dalam Cangara, 2011: 229) adalah sebagai berikut: " campaign is an organized effort conducted by one group (the change agent) which intends to persuade other (the target adopters), to accept, modify, or abandon certain ideas, attitudes, practices and behavior. Kampanye ialahsebuah upaya yang dikelola oleh satu kelompok, (agen perubahan) yang ditujukan untuk mempersuasi target sasaran agar bisa menrima memodifikasi atau membuang ide , sikap dan perilaku tertentu)" .

Merujuk pada definisidefinisi kampanye yang diungkapkan, maka setiap aktivis kampanye setidaknya harus mengandung 4 hal yakni :

a. Tindakankampanye yang ditujukan untuk menciptakan efek atau dampak tertentu;

b. Jumlah khalayak sasaran yang besar;

c. Biasanya dipusatkan dalam kurun waktu tertentu, dan

d. Melalui serangkaian tindakan komunikasi yang terorganisasi . Jadi, yang dimaksud kampanye adalah suatu kegiatan atau perilaku yang dilakukan untuk mengambil simpati masyarakat dengan cara menunjukkan atau menawarkan yang baik- baik atas dirinya, dan 
mengumumkan apa saja visi misi mereka untuk menduduki dan memimpin pemerintahan. (Jurnal Unila,2015)

\section{Macam- macam Kampanye}

Macam- macam kampanye banyak sekali jenisnya. Dilihat dari isinya dibagi menjadi 4 macam, yaitu :

a. Kampanye Positif

Kampanye positif adalah
kampanye yang lebih
cenderung mengenalkan calon
pemimpin atau presiden secara
pribadi, program kerja dan visi
misinya. Bentuk kampanye ini
bisa berupa slogan, baliho,
iklan tv, dialog, wawancara
ataupun debat. Kampanye inilah
yang harus dilakukan oleh para
calon. Kenyataannya baik
calon, tim ataupun fan dari
calon pemimpin sangat jarang
membahas ini, justru yang lebih
dilakukan adalah
mengkampanyekan kekurangan
lawan .

b. Kampanye Negatif

$\begin{array}{lr}\text { Kampanye negatif di } & \text { di } \\ \text { pilpres } 2014 \text { ini } & \text { sangat } \\ \text { terasa . Kampanye } & \text { negatif } \\ \text { cenderung menyerang } & \text { calon } \\ \text { pemimpin } & \text { secara } \\ \text { pribadi, walaupun demikian, } & \text { demisa } \\ \text { kampanye negatif ini juga bisa }\end{array}$

menyerang program kerja dari visi misi lawan politiknya . Dalam islam kampanye politik ini disebut juga "ghibah" yang artinya membicarakan kejelekan orang lain . Kampanye ini walaupun konotasinya jelek, namun sering dipakai agar pemilih berhati-hati dengan lawan politiknya dengan kekurangan yang ada pihak lawan politik. Kadang kampanye negative ini didasari dengan data dan fakta namun di opinikan dengan cara negatif .

c. Kampanye Abu-abu


menjelekkan pihak lawan namun data dan faktanya masih abuabu. Benar atau salahnya belum bisa dibuktikan. Cuma dikesankan bahwa pihak lawan politik adalah salah. Dalam kampanye abu-abu, antara kebenaran dan opini cenderung kuat opininya. Maka untuk perkara ini, belum bisa dibuktikan benar dan salahnya . Berbeda dengan kampanye negatif yang sudah sangat terlihat data dan faktanya dilapangan . 
d. Kampanye Hitam

Kampanye hitam adalah kampanye yang mengarah ke pembunuhan karakter dan cenderung fitnah . Isinya fitnah, kebohongan dan tuduhan tanpa bukti. Kampanye jenis inilah yang bisa dijerat hukuman, minimal dapat sanksi dari KPU jika tim capres melakukan kampanye ini . Kampanye hitam bagai sisi lain mata uang dari kampanye bersih yang terbuka. Dalam literasi barat, istilah black campaign atau kampanye hitam dikenal sebagai aktivitas menyudutkan, mendeskreditkan atau dalam tataran paling tinggi melalukan fitnah terhadap lawan atau rival politiknya ( www.islamcendikia.com) .

Direktur pusat studi politik Indonesia (puspol Indonesia) Ubedilah Badrun mengatakan Kampanye hitam atau black campaign dalam perspektif sosiologi politik adalah gejala politik yang diungkapkan oleh kontestan dengan niat dan niat buruk . ( www.harianterbit.com) Secara harfiah Black Campaign bisa diartikan sebagai kampanye kotor, yakni kampanye untuk menjatuhkan lawan dengan menggunakan isu negatif yang tidak berdasar. Dahulu kampanye hitam ini juga dikenal sebagai whispering campaign, yakni kampanye melalui mulut ke mulut, namun sekarang ini kampanye tersebut mengalami perubahan modus dengan menggunakan media massa sebagai penyebar informasi . ( www. Leadershippark.com)

Kampanye hitam yang menyudutkan kandidat banyak disebar melalui SMS, internet dan gosip dari mulut kemulut. Bahkan dengan perkembangan teknologi informasi yang makin canggih , lawan politik seseorang dapat direkayasa dalam bentuk foto dan gambar video yang amoral, meski akhirnya gambar hasil rekayasa seperti itu tidak apat dibuktikan kepalsuan dan kebenarannya (Cangara, 2011:295) .

Berdasarkan pada pengertian diatas maka dapat disimpulkan bahwa kampanye hitam adalah salah satu strategi kampanye yang digunakan para kandidat maupun tim untuk menjatuhkan 


\author{
lawan dengan cara \\ mengeluarkan isu yang tidak \\ benar dan terkesan fitnah.
}

\section{METODE PENELITIAN}

\section{A. Jenis Penelitian}

Penelitian merupakan suatu
pengolahan data yang dilakukan
dengan metode keilmuan tertentu yang
menghasilkan laporan ilmiah.
Kegiatan penelitian ditujukan untuk
memecahkan berbagai persoalan
Sesuai dengan permasalahan yang
ada, jenis penelitian yang dipakai
dalam penelitian ini adalah jenis
penelitian deskriptif dan pendekatan
yang dipakai dalam adalah
pendekatan kualitatif.

\section{B. Fokus Penelitian}

Dalampenelitianini, sesuai denganper masalahandantujuan , penelitimemandangperlu menggunaka nfokuspenelitianuntuk membatasi area ataubidangpermasalahan. Ditetapkann yafokus penelitianinimempunyaiduatuju an seperti yang dikemukakanoleh Moleong (2014:97) yaitu: Pertama, penetapanfokusmembatasistudi yang berartibahwadenganadanya fokus, pen entuantempatpenelitianmenjadilebihlay ak . Kedua, penentuanfokussecaraefek tif menetapkankriteriainklusieksklusi untukmenjaringinformasi yang mengalirmasuk. Mungkin data cukup menarik, tetapijikadipandangtida k relevan, data itutidakakandihiraukan . Dengan memperhatikan uraian diatas, maka yang menjadi fokus dalam penelitian ini adalah sebagai berikut:

1. Peran Komisi Pemilihan Umum (KPU) Kabupaten Tulungagung dalam mengatasi black campaign pada pelaksanaan Pemilu 2019 di Kabupaten Tulungagung;

2. Faktor pendorong dan penghambat peran Komisi Pemilihan Umum (KPU) Kabupaten Tulungagung pada pelaksanaan Kampanye Pemilu 2019 di Kabupaten Tulungagung .

\section{Lokasi Penelitian}

Lokasi penelitian merupakan tempat dimana peneliti melakukan penelitian dalam menangkap fenomena atau peristiwa yang sebenarnya terjadi dari objek yang diteliti. Peneliti menentukan lokasi berdasarkan pertimbangan rasional yang dapat dilakukan peneliti dengan tujuan pencapaian output penelitian dengan maksimal. Untuk mendapatkan kesesuaian di lapangan, (2014:128) Moleong menyebutkan bahwa, cara terbaik dalam menentukan lokasi 


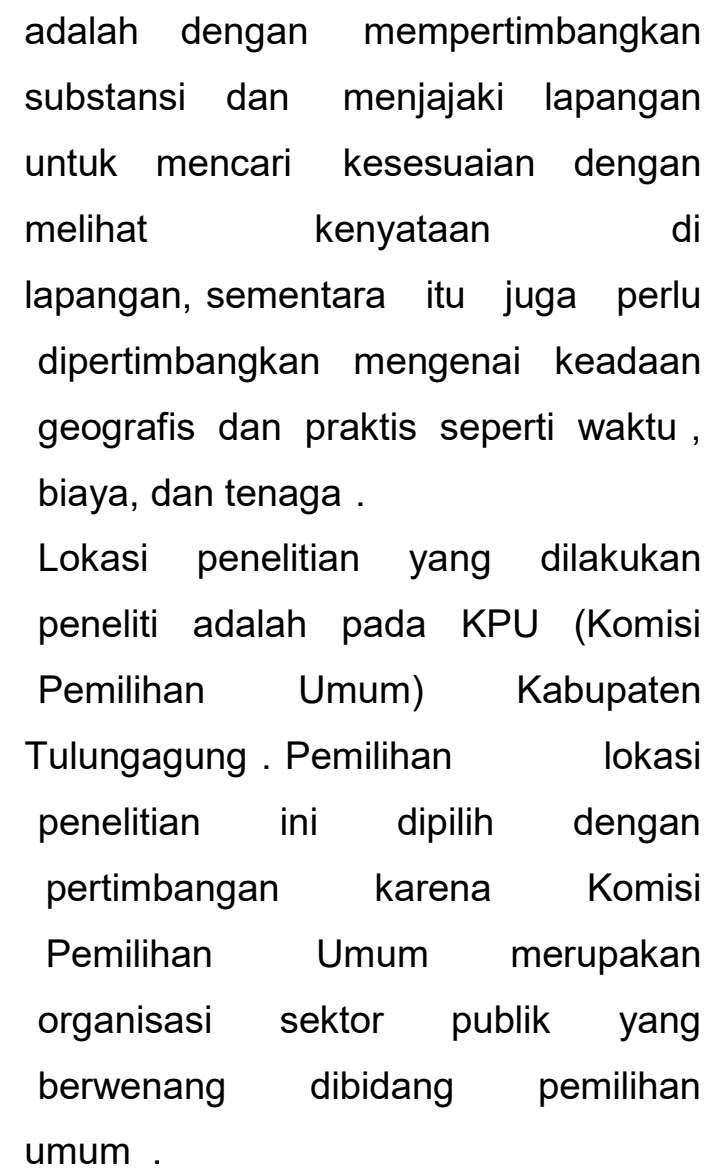

\section{D. eknik Pengumpulan Data}

Teknik pengumpulan data merupakan langkah yang paling utama dalam penelitian, karena tujuan utama dari penelitian adalah mendapatkan data. ( Sugiyono, 2016:224)

Dalam penelitian ini teknik pengumpulan data yang digunakan adalah :

\section{Observasi}

Observasi merupakan suatu
cara pengumpulan data dengan
melakukan pengamatan secara
langsung terhadap obyek
penelitian . Observasi dilakukan

dengan maksud untuk mendapatkan gambaran secara nyata tentang masalah yang sedang terjadi . Guba dan Lincoln (dalam Moleong, 2014:174) menyatakan, "salah satu alasan penggunaan metode observasi dalam penelitian kualitatif adalah memungkinkan melihat dan mengamati sendiri fenomena yang terjadi pada saat penelitian, kemudian mencatat perilaku dan kejadian sebagaimana yang terjadi pada keadaan sebenarnya" .

Penelitian ini mengumpulkan data dengan observasi terus terang atau tersamar, dimana dalam melakukan pengumpulan data peneliti menyatakan terus terang kepada sumber data bahwa ia sedang melakukan penelitian . Jadi mereka mengetahui sejak awal sampai akhir terkait aktivitas penelitian. Namun suatu saat peneliti juga tidak terus terang dalam melakukan observasi, hal ini untuk menghindari kalau ada suatu data yang dicari merupakan data yang masih dirahasiakan ( Sugiyono, 2016:228).

\section{Wawancara yang mendalam}

Esterberg mendefinisikan, (dalam Sugiyono, 


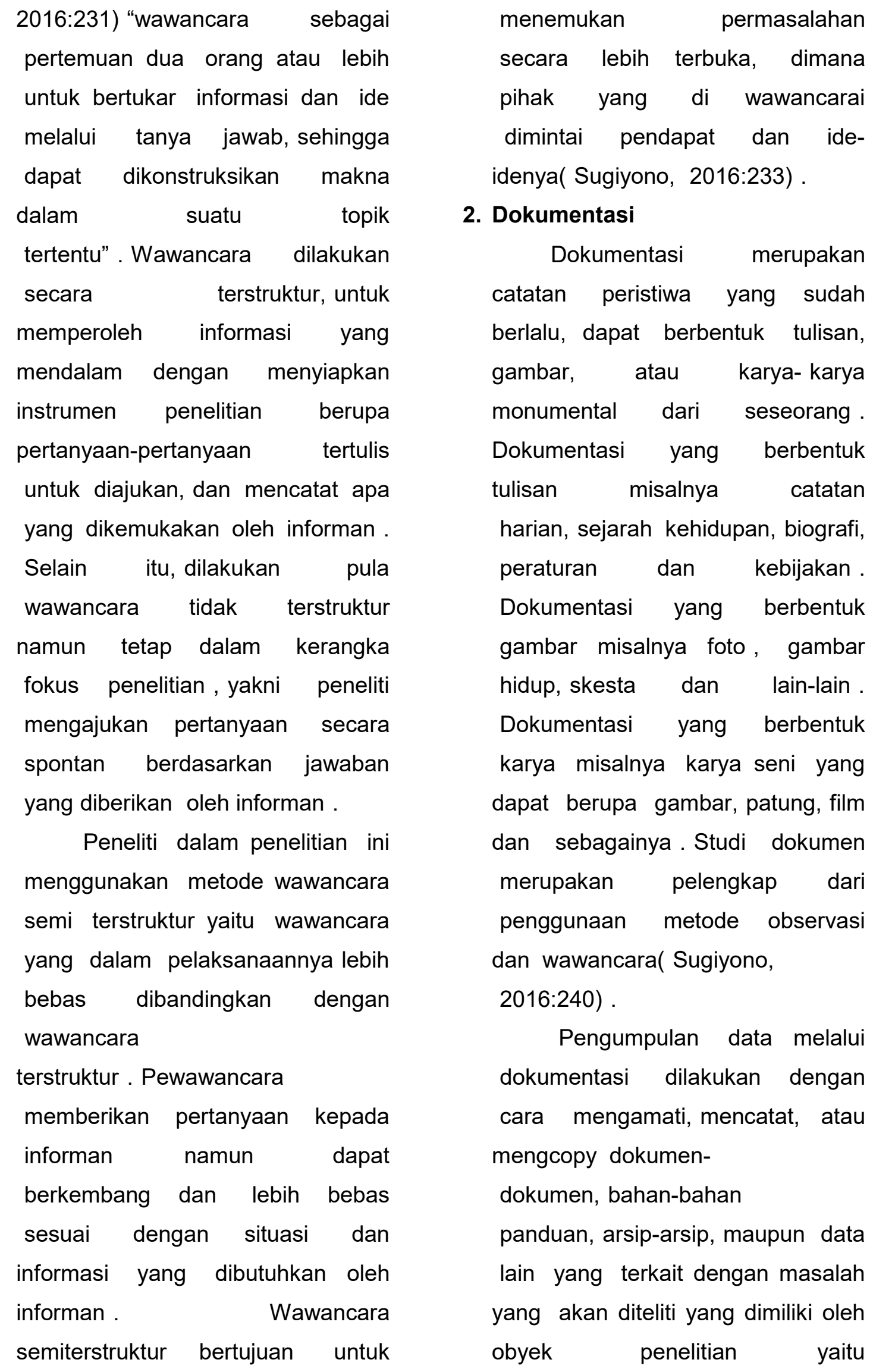


KomisiPemilihan Umum

(KPU)

Kabupaten Tulungagung .

\section{PEMBAHASAN}

\section{A. Gambaran Umum Lokasi Penelitian}

1. Sejarah Komisi Pemilihan Umum (KPU) Kabupaten Tulungagung

Menurut Undang-undang Nomor 22 Tahun 2007 Tentang Penyelenggara Pemilu, komposisi keanggotaan KPU memperhatikan keterwakilan perempuan sekurang-kurangnya $30 \%$ (tiga puluh persen). Masa keanggotaan KPU 5 ( lima) tahun terhitung sejak pengucapan sumpah/janji . Penyelenggara

Pemilu berpedoman kepada asas : mandiri; jujur; adil; kepastian hukum; tertib penyelenggara Pemilu; kepentingan umum; keterbukaan; proporsionalit as;

profesionalitas; akuntabilitas; efisie nsi dan efektivitas. Komisi Pemilihan Umum Kabupaten Tulungagung saat ini merupakan periode kedua, setelah periode pertama yang di bentuk tahun 2003 berdasarkan Undang- undang Nomor 12 Tahun 2003 ( Tentang Pemilu DPR, DPD dan DPRD) . Jumlah anggota KPU Kabupaten adalah 5 orang, dilantik pada tanggal 23 Juni 2003 untuk masa jabatan 5 Tahun atau berakhir pada tahun 2008. Hanya saja karena pada akhir tahun 2008 bertepatan dengan di laksanakan pemilihan Gubernur dan wakil Gubernur Propinsi Jawa Timur, maka berdasarkan Undang - undang nomor 22 tahun 2007 pasal 126 , masa kerja KPU Kabupaten dapat diperpanjang sampai 4 bulan setelah pelantikan gubernur dan wakil gubernur terpilih. Tanggal 1 April 2009 adalah pelantikan Anggota KPU Kabupaten Tulungagung masa jabatan 2009 2014 (Periode kedua). Anggota terpilih adalah Nyadin, Suyitno Arman, Mahsun Tohir, M. Fattah Masrun, dan Suprihno. Pelantikan dan pengambilan sumpah/janji dipimpin oleh Ketua KPU Provinsi Jawa Timur Nikmatul Hidayati, bertempat di Aula Kantor KPU Provinsi Jawa Timur, bersamaan dengan anggota KPU Kabupaten Probolinggo . Tidak ada masa

orientasi/pengenalan , karena pelantikan bertepatan dengan pelaksanaan Tahapan Pemilu 2009 , bahkan $\mathrm{H}-7$ sebelum hari pemungutan suara dihelat. Boleh dikata, 5 anggota KPU baru ini harus "siap pakai" dan "siap tempur" 


\begin{abstract}
terjun langsung ke gelanggang. Mereka harus melanjutkan sebagian tahapan yang sudah dikerjakan KPU periode sebelumnya . Tampaknya,

penyesuan diri dengan tugas-tugas baru bagi KPU baru ini tidak menjadi persoalan. Karena latar belakang/background mereka yang berbeda-beda sangat mendukung . Ada 2 anggota KPU lama. Ada mantan Ketua Panwaslu yang juga banyak berkecimpung di bidang Pers. Ada Dosen muda energik, dan tak ketinggalan penggiat LSM yang tentu saja "dekat" dengan dunia pergerakan dan aktifis demonstrasi. Lengkap sudah terasa, untuk membentuk sebuah "Team Work" yang tangguh dan kompeten .
\end{abstract}

1. Peran Komisi Pemilihan Umum (KPU) Kabupaten Tulungagung dalam Mengatasi "black campaign" yang Terjadi di Kabupaten Tulungagung



Suprihno, M.Pd selaku Ketua Komisi Pemilihan Umum (KPU) Kabupaten Tulungagung dalam wawancara hari Selasa tanggal 02 Juli 2019:

"Kalau tugas dan wewenang KPU dalam hal kampanye yang pertama, sebagaimana diatur dalam PKPU 23, 28,33, KPU mempunyai tugas memberikan fasilitas kepada peserta pemilu yaitu berupa dengan alat peraga kampanye" .

Adapun untuk titik lokasi pemasangan alat peraga kampanye ditentukan oleh KPU sendiri, sebagaimana yang ditambahkan oleh Bapak Drs. Mundiyar selaku Sekretaris Komisi Pemilihan Umum (KPU) Kabupaten Tulungagung dalam wawancara Hari Selasa tanggal 02 Juli 2019:

"Ya jadi untuk pemasangan APK memang ditentukan oleh KPU, tetapi penentuannya itu pertama yang ditentukan adalah titik-titik dimana daerah tersebut tidak diperbolehkan dipasang, jadi itu diberikan aturan terlebih dahulu, misalnya untuk daerah tertentu wilayah-wilayah tertentu , jalan-jalan mana saja yang tidak boleh diantaranya Jl. Diponegoro, Jl. Ahmad Yani Barat, Timur, Jl. R.A Kartini, itu tidak 
diperbolehkan. Tetapi juga ada titik-titik yang ditentukan untuk boleh dipasangi misalnya disepanjang Jl. Soekarno Hatta, disana boleh ataupun disepanjang jalan yang agak pinggir- pinggiran jalan, pokok selain yang tempat-tempat yang dilarang itu boleh kecuali untuk pemasangan baliho, baliho yang besar yang telah diberikan fasilitasi oleh KPU itu diatur, misalnya dalam satu dapil, 1 kecamatan itu ada wilayah tertentu yang dipasang disitu fasilitasnya, misalnya seperti di wilayah Campurdarat itu diseputaran pasar, kemudian diwilayah Bandung itu juga diseputaran pasar Bandung, untuk daerah Sumbergempol itu didaerah Jetaan, Gragalan, dsb . Ngntru juga seperti itu di utaranya Ngujang itu ada titik-titik yang sudah ditentukan, itu kaitannya dengan oenentuan fasilitasi, pemasangan" .

Dengan demikian tugas dan wewenang Komisi Pemilihan Umum (KPU) Kabupaten Tulungagung dalam hal kampanye yang pertama adalah memberikan fasilitas kepada peserta pemilu yaitu berupa alat peraga kampanye yang terdiri dari spanduk dan baliho. Adapun pemasangan alat peraga kampanye titik lokasinya ditentukan oleh KPU sendiri .

Selain itu tugas dan wewenang Komisi Pemilihan Umum (KPU) dalam hal kampanye adalah menentukan jadwal kampanye. Selain itu Komisi Pemilihan Umum (KPU) juga memberikan fasilitasi perijinan serta memberikan konsultasi pada peserta pemilu agar tidak melakukan hal-hal yang melanggar peraturan dalam pemilu .

Kampanye merupakan kegiatan yang wajib dilakukan oleh peserta pemilu, hal ini bertujuan untuk mengambil simpati masyarakat . Namun dalam pelaksanaannya tidak selalu dilakukan dengan baik, justru melanggar aturan yang telah ditetapkan yang biasa disebut dengan kampanye hitam (black campaign) . Kampanye hitam (black campaign) merupakan suatu pelanggaran sebagaimana yang dikemukakan oleh Bapak Agus Safei selaku anggota Komisi Pemilihan Umum (KPU) Kabupaten Tulungagung dalam wawancara pada Hari Selasa tanggal 02 Juli 2019:

"Black campaign merupakan salah satu bagian pelanggaran, kalau kampanye 
hitam sifatnya adalah fitnah sesuatu yang tidak benar tetapi kemudian dikatakan misalnya begini jadi orang ini misal A sebenarnya islam kemudian saat kampanye lawannya B mengatakan bahwa si $A$ ini tidak beragama islam dan seorang $\mathrm{PKI}$, berita bahwa si $A$ ini adalah $P K I$ itu dinamakan kampanye hitam dan itu tidak diperbolehkan" .

Jadi intinya adalah Komisi Pemilihan Umum (KPU) tidak punya wewenang penuh dalam penindakan, atau pemberian sanksi pada peserta pemilu yang melakukan pelanggaran. Dalam hal ini Badan Pengawas Pemilu (BAWASLU) lah yang mempunyai kewenangan sehingga apabila pelanggaran itu terjadi maka akan diproses oleh Badan Pengawas Pemilu (BAWASLU) kemudian akan diberikan sanksi sesuai dengan ketentuan yang ada .

Namun demikian Komisi Pemilihan Umum (KPU) juga berperan dalam mewujudkan pemilu yang langsung, umum, bebas, rahasia, jujur dan adil melalui pemahaman kepada masyarakat tentang pelanggaran dalam pemilu seperti kampanye hitam. Adapun peran Komisi Pemilihan Umum (KPU) Kabupaten Tulungagung dalam mengatasi kampanye hitam (black campaign) adalah dengan memberikan pemahaman kepada peserta pemilu tentang apa itu kampanye hitam (black campaign) melalui sosialisasi agar peserta kampanye memahami serta tidak melakukan kampanye hitam (black campaign .

2. Faktor Pendorong dan Penghambat Peran Komisi Pemilihan Umum (KPU) Kabupaten Tulungagung pada Pelaksanaan Kampanye Pemilu 2019 di Kabupaten Tulungagung

\section{a. Faktor Pendorong}

Adapun faktor pendorong peran Komisi Pemilihan Umum (KPU) Tulungagung pada pelaksanaan kampanye Pemilu 2019 di Kabupaten Tulungagung adalah sebagai berikut :

1) Antusiasme masyarakat

Sukses atau tidaknya pemilihan umum salah satunya bisa diukur dari antusias tidaknya masyarakat pada penyelenggaraan even tersebut. Antusiasme tersebut jelas terlihat dari banyaknya masyarakat yang mulai mencari tahu track record calon presiden dan caleg, baik melalui media cetak, elektronik dan online, serta menonton debat capres 
untuk melihat sejauh mana visi dan misi masing-masing capres, guna menentukan pilihan .

2) Pemahaman masyarakat yang relatif bagus terhadap Pemilu Adanya sosialisasi yang dilakukan oleh pihak penyelenggara maupun kampanye yang dilakukan oleh masing-masing calon sebelum penyelenggaraan pemilu, tentu menjadi suatu alat bagi masyarakat untuk melakukan pengamatan yang berdampak bagi pemahaman masyarakat akan pentinya pemilu. Pemahaman masyarakat yang bagus ini, berpengaruh terhadap partisipasi dan peran masyarakat (partisipasi politik) .

3) Support dari instansi terkait Suatu kegiatan yang dilakukan akan berjalan dengan baik apabila terdapat kerjasama yang baik. Suksesnya pemilu bukan hanya bersandar pada integritas Penyelenggara Pemilu dan peserta pemilu saja . Namun demikian, harus didukung seluruh pemangku seluruh pemangku pemilu demi terciptanya sinergitas yang kuat dan saling berkesinambungan . Dengan demikian, sangat diperlukan adanya kerjasama yang bagus antara pemerintah dan jajarannya dalam upaya meningktakan kualitas demikrasi baik secara procedural maupun substansial. Dengan adanya support dan dukungan ${ }^{1}$ dari instansi yang terkait, maka pemilu sebagai pesta demokrasi harus dapat menjamin hak politik masyarakat .

\section{b. Faktor Penghambat}

Adapun faktor penghambat peran Komisi Pemilihan Umum (KPU) Tulungagung pada pelaksanaan kampanye Pemilu 2019 di Kabupaten Tulungagung adalah sebagai berikut :

1) Penggunaan Media Sosial yang Tidak Semestinya

Media sosial dengan segala kemudahannya seharusnya dimanfaatkan untuk berinterksi dan menyebarkan pesan positif . Akan tetapi hal tersebut digunakan oleh oknum yang tidak bertanggungjawab untuk menyebarkan informasi negatif. Facebook, Twitter, Instragram WA hanyalah 
sebagian kecil media sosial yang digunakan dalam penyebaran hoax. Konten hoax biasanya bernada provokatif, adu domba melalui isu SARA, dan kampanye hitam (black champaign) .

Tersebarnya berita hoak di media sosial terjadi karena lemahnya minat pembaca untuk mencerna isi dalam sebuah berita. Oleh karena itu seharusnya kini masyarakat menggunakan media sosial dengan mengetahui dari mana sumber berita tersebut berasal. Selain itu juga harus bertanya dan klarifikasi kepada orang lain .

2) Pragmatisme Masyarakat Pragmatis masyarakat diartikan sebagai tercapainya keinginan masyarakat dengan menempuh cara atau jalur yang bersifat jangka pendek, di mana logika dan praktiknya didasarkan pada transaksi material yang diterima dalam memilih . Munculnya pragmatis pemilih dapat diakibatkan dari sikap apatis pemilih sebagaimana di uraikan di atas, kurangnya pemahaman akan hak-hak politik warga negara, dan kemanfaatan politik . Terkadang, sikap pragmatis lahir sebagai wujud resistensi pemilih terhadap partai politik, para anggota legislatif, dan kepala daerah, di mana para elite politik tersebut cenderung kurang memberikan perhatian atau lupa pada saat duduk di kursi kekuasaan .

\section{KESIMPULAN}

Dari hasil penelitian yang telah dilakukan peneliti dalam hal ini berkaitan dengan judul "Peran KPU dalam Mengatasi Black Campaign " Studi di Kantor KPU Kabupaten Tulungagung, dengan mengacu pada hasil penelitian dan pembahasan maka peneliti dapat memberikan kesimpulan sebagai berikut:

1. Komisi Pemilihan Umum (KPU) tidak punya wewenang penuh dalam penindakan terhadap pelaku pelanggaran seperti kampanye hitan (black campaign). Penindakan terhadap pelaku pelanggaran menjadi tugas dan wewenang dari Badan Pengawas Pemilu (BAWASLU) . Adapun peran Komisi Pemilihan Umum (KPU) dalam mengatasi kampanye hitam (black campaign) di

Kabupaten 
Tulungagung adalah dengan

memberikan pemahaman kepada peserta pemilu melalui sosialisasi agar peserta kampanye memahami serta tidak melakukan kampanye hitam (black campaign) .

2. Adapun faktor pendorong peran komisi pemilihan umum (KPU) Kabupaten Tulungagung pada pelaksanaan kampanye pemilu 2019 di kabupaten tulungagung antara lain dapat dilihat dari:

a. Antusiasme Masyarakat

b. Pemahaman masyarakat yang relatif bagus terhadap Pemilu

c. Support dari instansi terkait Sedangkan faktor penghambat peran komisi pemilihan umum (KPU) Kabupaten Tulungagung pada pelaksanaan kampanye pemilu 2019 di kabupaten tulungagung antara lain dapat dilihat dari:

a. Penggunaan media sosial yang tidak semestinya

b. Sikap pragmatisme masyarakat

\section{Saran}

Dari uraian hasil penelitian di lapangan dan pembahasan yang disesuaikan dengan teori serta hasil kesimpulan, maka dapat direkomendasikan saran-saran sebagai berikut:
1. Komisi Pemilihan Umum (KPU) beserta Badan Pengawas Pemilu (BAWASLU) selain bekerjasama dengan instansi terkait seperti Dinas Komunikasi dan Informatika, juga harus bersinergi dengan perusahaan penyedia aplikasi media sosial seperti facebook, whatsapp, instagram, dan lain sebagainya untuk menekan penyebaran konten negatif atau hoak .

2. Komisi Pemilihan Umum (KPU) sebagai penyelenggaran pemilu harus lebih memperbanyak sosialisasi baik secara langsung maupun melalui media sosial tentang pemilu dan apa saja yang dilarang dalam pemilu agar masyarakat bisa lebih memahami dan bisa lebih berfikir kritis .

\section{DAFTAR PUSTAKA}

\section{Buku}

Arikunto, Suharsimi. 2002. Metodologi Penelitian. Penerbit PT. Rineka Cipta. Jakarta .

Asshiddiqie, Jimly. 2006. Konstitusi dan Konstitusionalisme Indonesia, edisi revisi, Jakarta:Sekretaris Jendral dan Kepaniteraan Mahkamah Konstitusi Republik Indonesia .

Cangara, Hafied. 2011. Komunikasi Politik Konsep, Teori, dan Strategi. Jakarta: PT. Raja Grafindo Persada .

Hakim, Lukman. 2010. Parameter untuk Melembagakan Komisi Negara sebagai Lembaga Negara dalam 
Konstitusionalisme Demokrasi, Sebuah diskursus tentang Pemilu, Otonomi Daerah, dan Mahkamah Konstitusi sebagai Kado untuk Sang Penggembala Prof. A. Mukthie Fadjar, S.H., M.S. Malang : InTrans.

Moleong, Lexy J. 2014. Metodologi Penelitian Kualitatif. PT Remaja Rosdakarya. Bandung .

Natabaya, Ahmad Syarifuddin. 2008. Menata Ulang Sistem Peraturan perundang-undangan di Indonesia: Jejak Langkah dan Pemikiran Hukum Prof. H.A.S. Natabaya, S.H., LL.M. Jakarta: Setjen Kepaniteraan MK

$\begin{array}{lr}\text { Prihatmoko, Joko } & \text { J. 2003. Pemilu } \\ 2004 \text { dan } & \text { Konsolidasi } \\ \text { Demokrasi. } & \text { Semarang: LP2I } \\ \text { Press. } & \end{array}$

Rizkiyansah, Ferry Kurnia. 2007. Mengawal Pemilu Menatap Demokrasi: Catatan Penyelenggaran Pemilu 2004. Bandung: CV Alia Grafika

Soekanto, Soerjono, 2002, Teori Peranan, Jakarta, Bumi Aksara.

Soedarsono, 2005. Mahkamah Konstitusi Sebagai pengawal Demokrasi, Penyelesaian

Sengketa Hasil Pemilu Oleh Mahkamah

Konstitusi, Jakarta: Sekretariat Jenderal dan Kepaniteraan Mahkamah Konstitusi RI.

Sugiyono. 2016. Metode Penelitian Kuantitatif, Kualitatif dan R\&D. PT Alfabet. Bandung.

Tricahyo, Ibnu, Reformasi Pemilu Menuju Pemisahan Pemilu Nasional dan. Lokal, ( Malang: In-Trans Publishing, 2009)

\section{Jurnal}

Jurnal Unila, 2015

\section{Undang-Undang}

Undang-Undang Nomor 8 Tahun 2012 Tentang Pemilihan Umum Anggota Dewan Perwakilan Rakyat, Dewan Perwakilan Daerah, dan Dewan Perwakilan Rakyat Daerah.

Undang Undang Nomor 42 Tahun 2008 Tentang Pemilihan Presiden dan Wakil Presiden

Undang-Undang Nomor 7 Tahun 2017 Tentang Pemilihan Umum

Badan Pengawas Pemilu Nomor 6 Tahun 2014 Tentang Pedoman Pengawasan Pemilu

Peraturan Komisi Pemilihan Umum Republik Indonesia Nomor 33 Tahun 2018 tentang Perubahan Kedua atas Peraturan Komisi Pemilihan Umum Nomor 23 Tahun 2018 tentang Kampanye Pemilihan Umum

\section{Internet}

https://www.republika.co.id/ diakses tanggal 28 April 2019 https://www.tulungagungtimes.com/ diakses tanggal 28 April 2019 https://www.harianterbit.com/ diakses tanggal 30 April 2019 https://www.islamcendikia.com/ diakse s tanggal 30 April 2019 https://www.leadership-park.com/ diakses tanggal 30 April 2019 